\title{
The Assessment of Risk Management and the Main Characteristics of a Proactive Educational System in Romania
}

\author{
Monica RADUCAN ${ }^{\star}$, Tincuta VRABIE ${ }^{\star \star}$, Aura COLAN ${ }^{\star \star \star}$, Natalia BULGARU ${ }^{\star \star \star \star}$, \\ Nicoleta CRISTACHE ${ }^{\star \star \star \star \star}$, Adriana MATEI ${ }^{\star \star \star \star \star \star}$
}

\begin{tabular}{l}
\hline \multicolumn{1}{c}{ A R T I C L E I N F O } \\
\hline Article history: \\
Accepted August 2020 \\
Available online August 2020 \\
\hline JEL Classification \\
G32 \\
Keywords: \\
Risk, Management, School, \\
Proactive
\end{tabular}

A B S T R A C T

The paper addresses risk management in Romanian pre-university educational system. The first part presents theoretical information on the concept of risk, risk management and the process of identification, assessment and control of risks. The application part analyzes the risks that may occur in Romanian schools, respectively an analysis on the probability of risk occurrence, their impact and level, alongside the countermeasures established and implemented by schools in Romania.

(C) 2020 EAI. All rights reserved.

\section{Introduction}

Risk management, acknowledged, assumed and treated with the utmost care, can guide a school towards the trend of the proactive ones. This approach becomes a topical issue in the context in which we observe what the main risks are faced by schools in Romania, what are the causes of these risks and how they can be combated so as to cope with the pressure of the local community (Datnow A., Hubbard L., Mehan H., 2005).

Basically, educational institutions should, on the one hand, become more responsible for the way they manage their activities, and on the other hand, they have the obligation to respond to the needs of society, providing quality educational services to students (Voinea C.M., 2016).

Broadly speaking, schools must also learn to be efficient, effective and economical in the public domain, i.e. to provide "more" (more prepared students) with "less" (using fewer resources).

From our point of view, students are the essence of a community, and their perspective can lead to new ways of thinking about schools. The opinion of students and parents matters a lot in identifying new risks and eliminating them in a timely manner (Bérard C., C. Teyssier, 2007).

Through this paper we aim to identify, from the perspective of students, a series of risks, considered relevant, from the whole environment in which schools operate (Bohn C, B. Kemp, 2006).

The paper approaches from a theoretical point of view the concept of risk, risk management and respectively the whole process that is necessary to go through in order to avoid certain unforeseen situations that may occur in carrying out various activities. The approach is complemented by an analysis of the level of likelihood of risks, the level of impact that the risk may have and how exposed schools are to those risks. We also identified some methods to combat these risks implemented by schools in Romania.

\section{Literature review}

At the time of establishment, any entity sets certain objectives that it wishes to achieve, and throughout its activity it will make every effort to achieve them. This feature is not only specific to the private sector or where the result is profit, it must be pursued in the public domain and even more, where the result is the training of new specialists. Consequently, the achievement of these objectives also involves continuous work, which is associated with several risks (Peter McCaffery, 2018).

Knowing and identifying these risks facilitates the efficient and effective achievement of the set objectives. But what exactly is this "risk"? 
Risk represents "a problem that has not yet arisen, but which may arise in the future, in which case the achievement of pre-determined results is threatened or potentiated. In the first situation, the risk is a threat, and in the second, the risk is an opportunity (Clark M., Munn P., 2005).

Risk represents uncertainty in achieving the desired results and should be analyzed as a combination of probability and impact. " Simplified, the risk is a future event, possible but uncertain, resulting in damage."

We find the source of the risk both inside the entity and outside it. Thus, two categories of risk sources can be distinguished, namely: external sources and external sources (Ciucescu, D. and V. Simionescu, Gh., 2006). External sources are those sources of risk that result from events outside the entity that do not depend on internal activity and cannot be controlled. For example, a government law or ordinance that affects certain ongoing activities or projects may be considered an external source of risk because it is not generated by the entity but directly affects it. Internal sources represent the result of events within the entity, but which, unlike external ones, can be controlled and prevented by identifying them and eliminating the causes that produce them. For example, the risks of using technological equipment can be eliminated by upgrading or the risks of the workforce can be eliminated or limited by training staff (Tomlinson H., 2004).

In order to control the risk as effectively as possible, it is necessary to identify it as early as possible. A simple way to identify the risks would be to determine the cause, to recognize the "uncertain event" that may occur, to determine the events that would lead to the next "effect" on the company's objectives (Smyth J, 2005).

According to the Methodology for implementing the Internal Control Standard, the main risk categories are:

a. Inherent risk - that risk which arises before any measure is taken to mitigate its occurrence in order to reduce its effect. It exists in any activity carried out by the entity.

b. Residual risk - is the display caused by a certain risk after taking measures to mitigate it. Basically, the residual risk is the risk remaining after the application of internal control measures.

Within entities, a well-developed risk strategy is pursued in order to identify and eliminate risks. This strategy is the organization's general approach to risk. It must be documented and easily accessible in the organization (Iosifescu, S., et al., 2003). The risk strategy defines risk tolerance.

In order to manage risks as efficiently as possible, it is necessary to identify, assess and determine a way to react to them, i.e. to apply effective means of internal control with which the risk can be minimized or mitigated (Ghergut, A., 2007). This approach is embodied in risk management, which involves "all processes for identifying, assessing and assessing risks, establishing responsibilities, taking the necessary measures to mitigate them, periodically reviewing and monitoring progress." (Ministry of Public Finance, Methodology for implementing the Internal Control Standard "Risk Management", 2007) "

According to current legislation, "the public entity systematically analyzes, at least once a year, the risks related to its activities, draws up appropriate plans to limit the possible consequences of these risks, and appoints employees responsible for implementing those plans." (Ministry of Finance Public, Methodology for implementing the Internal Control Standard "Risk Management", 2007).

Furthermore, the manager has the obligation to create and maintain a healthy internal / managerial control system, mainly by (Dimmock, C. A. J., Donoghue, T. A, 2005):

a. identification of major risks that may affect the effectiveness and efficiency of operations, compliance with rules and regulations, protection of property, prevention and detection of fraud;

b. defining the acceptable level of exposure to these risks;

c. assessing the probability that the risk will materialize and the magnitude of its impact;

d. monitoring and assessment of risks and the adequacy of internal controls to risk management;

e. checking the budget execution report, including the one on programs.

Consequently, according to the national regulations in the field, the implementation of risk management represents the major responsibility of the management of the public entity, and the evaluation of the functionality is the responsibility of the internal audit (Standard 11 - OMFP 946/2005 republished)

\section{Research objectives and methodology}

Schools are constantly subject to legislative changes and international pressure so that they must face ongoing challenges in terms of the risks that surround them. Regarding the methodology for applying risk management, this is done through various means (Voinea C., 2016):

1. Identification of associated risks - is done by evaluating auditable operations, determining the expected internal controls and depending on this determining the risks. Risk identification involves the following:

a. Initial identification of risks, in the case of entities that have not previously identified them;

b. Risk identification in the case of entities that have implemented a risk management process. For the entity to achieve an efficient risk management, it is necessary to develop a permanent process of their identification that allows the adaptation of the public entity to the change process. 
2. Risk assessment - the risk assessment process includes both the assessment of the inherent risks, existing before the implementation of the control measures, and the residual risks resulting after the implementation of the control measures. The risk assessment consists of:

a. The probability of materialization of the risks, which implies the possibility or eventuality that a risk will occur. It can be expressed on a three-level scale of values:

Table 1- Probability level

\begin{tabular}{|c|c|}
\hline Probability & Conditions of occurrence \\
\hline Low (1) & $\begin{array}{l}\text { Rare changes in the regulatory framework, over } 3 \text { years; } \\
\text { Reduced complexity of activities and actions; } \\
\text { Experienced staff (experience at least } 5 \text { years); } \\
\text { Objectives and targets are not changed; } \\
\text { Reliable, adequate and up-to-date information; } \\
\text { Well-designed, formalized and managed processes; } \\
\text { The risk did not materialize before. }\end{array}$ \\
\hline Medium (2) & $\begin{array}{l}\text { The normative framework is relative or has undergone significant changes; } \\
\text { The average complexity of activities and actions; } \\
\text { Average level of staffing and experience (under } 3 \text { years); } \\
\text { Rare changes in goals and targets; } \\
\text { Existing information in several sources but insufficient; } \\
\text { Risk has rarely occurred in the past. }\end{array}$ \\
\hline High (3) & $\begin{array}{l}\text { Very frequent changes of the normative framework; } \\
\text { High complexity of activities and actions; } \\
\text { Inexperienced and newly hired staff (less than one year experience) } \\
\text { Frequent changes in objectives and targets; } \\
\text { Poorly designed, formalized and managed processes; } \\
\text { Insufficient and outdated information. }\end{array}$ \\
\hline
\end{tabular}

b. Estimating the impact on the objectives / activities in case of materialization of risks, an impact which represents the negative consequence that can affect the educational process. This can be low, moderate or high impact, each type being presented in table no. 2:

Table 2- Level of impact

\begin{tabular}{|c|c|}
\hline Impact & Conditions of occurrence \\
\hline Low (1) & $\begin{array}{l}\text { No loss of assets (financial, employees, materials) } \\
\text { The damage to the entity's image is reduced } \\
\text { Operating costs are not affected } \\
\text { The quality of the services provided is not affected } \\
\text { There are no interruptions in activity }\end{array}$ \\
\hline Moderate (2) & $\begin{array}{l}\text { Reduced asset losses; } \\
\text { The damage to the entity's image is moderate; } \\
\text { The increase in operating costs is moderate; } \\
\text { The quality of the services provided is affected to a small } \\
\text { extent; } \\
\text { There are small interruptions in activity. }\end{array}$ \\
\hline High (3) & $\begin{array}{l}\text { Significant loss of assets; } \\
\text { The entity's image is significantly affected; } \\
\text { High operating costs; } \\
\text { The quality of services provided is significantly affected; } \\
\text { Significant interruptions in activity. }\end{array}$ \\
\hline
\end{tabular}

Source: Adaptation to Guidance - Risk assessment in the preparation and implementation of public internal audit missions, 2014, page 14

c. The assessment of risk exposure, which is determined by the product between the probability and the impact of the risk, thus determining the total score, which will be highlighted in the following table: 
Table 3- Establishing the total risk score

\begin{tabular}{|c|c|c|c|c|}
\hline High (3) & \multirow{3}{*}{$\begin{array}{l}\overleftarrow{U} \\
\stackrel{\Xi}{0} \\
\stackrel{\Xi}{\Xi}\end{array}$} & 3 & 6 & 9 \\
\hline Moderate (2) & & 2 & 4 & 6 \\
\hline \multirow[t]{3}{*}{ Low (1) } & & 1 & 2 & 3 \\
\hline & & \multicolumn{3}{|c|}{ PROBABILITY } \\
\hline & & Low (1) & Medium (2) & $\operatorname{High}(3)$ \\
\hline
\end{tabular}

Following the determination of the total risk score, they can be classified into 3 categories: high risks, medium risks and low risks, as follows:

- For total score $=1$ or 2 the risk is low (green colour) does not require control measures;

- For total score $=3$ or 4 the risk is medium (yellow colour) requires medium- or long-term control measures;

- For total score $=6$ or 9 the risk is high (red colour) requires urgent control measures

3. Risk management - consists in taking control measures for the inherent risks, thus taking into account first the risks with high exposure (red colour) and then the medium risks (yellow colour), wishing that the risks with low exposure are monitored at the compartment level.

4. Risk monitoring - is performed based on a plan for implementing control measures and through the risk follow-up sheet.

5. Periodic review and reporting of risks - the final stage that concludes the risk management process. The review is performed due to major changes in the entity's objectives or changes in risk profiles, and examines whether: risks persist, new risks have been identified, impact and likelihood have changed, internal control instruments that are put in place. application is effective. Risk reporting is performed annually on two levels: at the level of compartments and at the level of the public entity.

Therefore, we can state that risk management represents an important means by which an efficient and effective control system is introduced at the level of the public entity. Consequently, the main objective of this paper aims to identify from the perspective of students, a series of risks, considered important by us, from the whole environment in which schools operate.

\section{Risk analysis at the level of school units in Romania}

Achieving the main objective of this study was materialized by analyzing the main risks that a proactive school may encounter during the activity.

Thus, in the light of the main objective pursued, we identified four other secondary objectives, for analysis, as follows:

- Identifying the main risks at the level of a university;

- Identifying the cause for the relevant risks;

- Identifying the probability of occurrence, impact and level of risk exposure;

- Identifying methods to combat risks.

Peter McCaffery, in his book The Higher Education Manager's Handbook: Effective Leadership and Management in Universities and Colleges, identifies several prerequisites for a school to be effective and become a leader in a community. The requirements identified by the author helped us to group the risks faced by a school (Figure 1) and which it must combat in order to become one of the pillars of education.

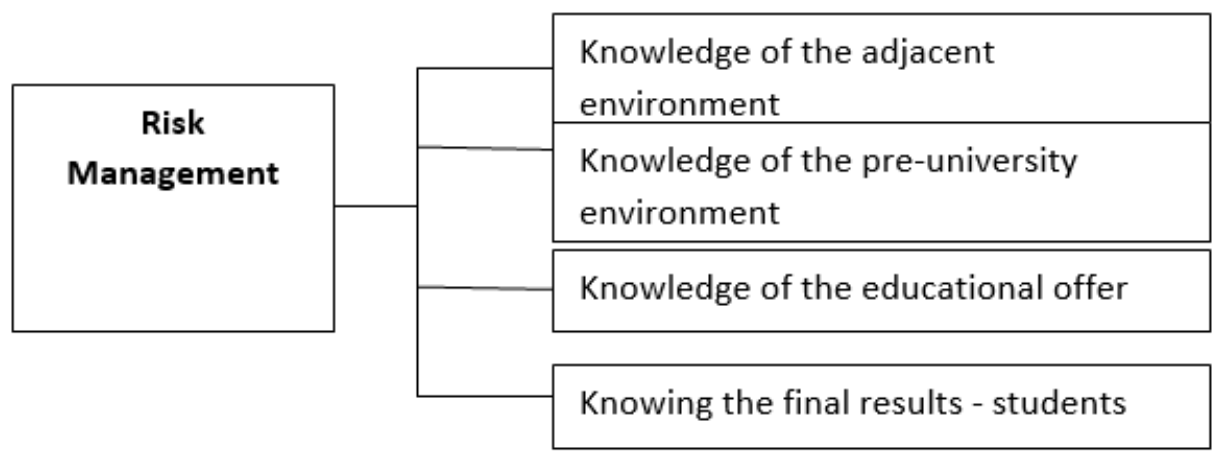

Figure 1 - The main risks identified at the level of a school Source: made by the authors 
Following these premises, we will identify and analyze risks specific to each category (Table 4), considered by us important and relevant to have a proactive school.

Table 4 - Risk determination

\begin{tabular}{|c|c|}
\hline \multirow{6}{*}{$\begin{array}{l}\text { KNOWLEDGE OF THE } \\
\text { ADJACENT } \\
\text { ENVIRONMENT }\end{array}$} & Low notoriety of the school unit compared to other schools \\
\hline & Lack of laboratories / teaching spaces or their non-modernization \\
\hline & IT logistics issues \\
\hline & Unfavorable positioning \\
\hline & Insufficiently developed infrastructure in terms of transport \\
\hline & Lack of extracurricular programs of interest to students with certain skills \\
\hline \multirow{4}{*}{$\begin{array}{l}\text { KNOWLEDGE OF THE } \\
\text { EDUCATIONAL OFFER }\end{array}$} & Possibility to set up special classes / study groups \\
\hline & Insufficient teacher-student and / or teacher-parent communication \\
\hline & Possibilities of fraud \\
\hline & Failure to meet the set objectives \\
\hline \multirow{4}{*}{$\begin{array}{l}\text { KNOWLEDGE OF THE } \\
\text { PRE-UNIVERSITY } \\
\text { ENVIRONMENT }\end{array}$} & Delay in funding from the ministry \\
\hline & Lack of own funding sources (e.g. projects) \\
\hline & Failure to attract additional sources of funding \\
\hline & Failure to meet the established indicators \\
\hline \multirow{5}{*}{$\begin{array}{l}\text { KNOWLEDGE OF FINAL } \\
\text { RESULTS - STUDENTS }\end{array}$} & School dropout \\
\hline & Decreasing the number of students \\
\hline & Lack of integration programs for students with disabilities \\
\hline & Low number of extracurricular programs \\
\hline & Decreasing the fund of social scholarships \\
\hline
\end{tabular}

Following the method used in the risk assessment presented above, we performed an analysis of a risk in each category presented in the case study, a risk that we considered to be the most important.

Thus, Table 5 presents an examination of the following types of risks:

- the risk of dropping out of school,

- the risk of a class dissolution,

- the risk of not realizing one's own funding sources,

- the risk that students will prefer other better rated schools.

Their analysis was made in terms of the level of probability of occurrence of risks, the level of impact that the risk may have and the level of exposure of schools to those risks.

At the same time, we tried to identify a series of more common methods to combat these risks, implemented by some schools in Romania or that can be implemented to maintain a high standard and to remain proactive.

Tabel 5 - Risks analysis

\begin{tabular}{|c|c|c|}
\hline \multirow{6}{*}{$\begin{array}{l}\text { KNOWLEDGE OF FINAL } \\
\text { RESULTS - STUDENTS } \\
\text { School dropout }\end{array}$} & Causes & $\begin{array}{l}\text { - students cannot adapt to the school curriculum } \\
\text { - financial impossibility to continue, } \\
\text { - lack of interest, } \\
\text { - family causes }\end{array}$ \\
\hline & Probability level & High \\
\hline & Score & 3 \\
\hline & Level of impact & Moderate or even high (score $2-3$ ) \\
\hline & Control methods & $\begin{array}{l}\text { Organizing counseling activities, implementing } \\
\text { programs aimed at reducing school dropout, } \\
\text { stimulating students with good results by providing } \\
\text { scholarships, etc. }\end{array}$ \\
\hline & \multicolumn{2}{|c|}{$\begin{array}{l}\text { Applying the method presented above (the product between the score and the } \\
\text { impact) results in a total score between } 6 \text { and } 9 \text {, a score related to high risk. }\end{array}$} \\
\hline \multirow{5}{*}{$\begin{array}{l}\text { KNOWLEDGE OF THE } \\
\text { EDUCATIONAL OFFER } \\
\text { Dissolution of a class of } \\
\text { students }\end{array}$} & Causes & the number of students decreases from year to year \\
\hline & Probability level & Medium \\
\hline & Score & 2 \\
\hline & Level of impact & Medium (score 2) to high (score 3). \\
\hline & Control methods & $\begin{array}{l}\text { Promotion campaigns carried out in different schools, } \\
\text { establishing a day like "Open Doors" for school visits, } \\
\text { etc. }\end{array}$ \\
\hline
\end{tabular}




\begin{tabular}{|c|c|c|}
\hline & \multicolumn{2}{|c|}{ between 4 and 6 , which indicates that the risk is medium to high. } \\
\hline \multirow{6}{*}{$\begin{array}{l}\text { KNOWLEDGE OF THE } \\
\text { PRE-UNIVERSITY } \\
\text { ENVIRONMENT } \\
\text { Failure to achieve own } \\
\text { funding sources }\end{array}$} & Causes & $\begin{array}{l}\text { Failure to meet the deadlines for receiving budget } \\
\text { allocations }\end{array}$ \\
\hline & Probability level & Medium \\
\hline & Score & 2 \\
\hline & Level of impact & Medium (score 2) \\
\hline & Control methods & $\begin{array}{l}\text { Existence of a reserve fund that can be activated in } \\
\text { the event of such situations. }\end{array}$ \\
\hline & \multicolumn{2}{|c|}{$\begin{array}{l}\text { In this way we can determine the risk score as } 4 \text {, resulting in the risk being } \\
\text { medium. }\end{array}$} \\
\hline \multirow{6}{*}{$\begin{array}{l}\text { KNOWLEDGE OF THE } \\
\text { ADJACENT } \\
\text { ENVIRONMENT } \\
\text { Students' preference for } \\
\text { inappropriate practical } \\
\text { activities }\end{array}$} & Causes & $\begin{array}{l}\text { Predisposition of some students to accept practical } \\
\text { activities inappropriate for their age }\end{array}$ \\
\hline & Probability level & Medium \\
\hline & Score & 2 \\
\hline & Level of impact & Medium (score 2) \\
\hline & Control methods & $\begin{array}{l}\text { Partnering with different institutions to develop } \\
\text { practical skills in students to adapt faster and easier } \\
\text { to the requirements of today's society. }\end{array}$ \\
\hline & \multicolumn{2}{|c|}{$\begin{array}{l}\text { In this way we can determine the risk score as } 4 \text {, resulting in the risk being } \\
\text { medium. }\end{array}$} \\
\hline
\end{tabular}

Following the data analyzed in the previous table, we can conclude that these risks can influence the activity of schools in a worrying way. We can notice that pre-university education institutions in Romania try to control the effects of these risks through the various control methods exemplified in the table, but in order to become proactive schools it is necessary to develop more comprehensive and effective control methods, which should be carried out continuously.

\section{Conclusions and suggestions}

For the pre-university school system in Romania to be considered proactive, it is necessary to have a very good command of this risk management procedure and to implement it in a professional manner. Through efficient and effective risk management, school units can prove that they are not just "educational institutions" but are true "learning organizations" and thus can enter the trend of schools with high confidence. Risk management and control should not be seen as a burden, as an additional responsibility exercised at the level of school inspectorates and the management team in each school but should be regarded as opportunities to determine and solve possible problems associated with unwanted events.

\section{References}

1. Bérard C., C. Teyssier (Eds.), Risk management: Lever for SME development and stakeholder value creation, Wiley-ISTE, 2017, pp. 6583;

2. Bohn C, B. Kemp, Enterprise risk management quantification-an opportunity, Paper presented at enterprise risk management symposium, Chicago, IL , 2006;

3. Ciucescu, D. and V. Simionescu, Gh., Managementul calității in învățământul preuniversitar. Editura Didactică și Pedagogică, București, 2006;

4. Clark, Margaret, Munn, Pamela, Education in Scotland: Policy and Practice from Pre-School to Secondary, Taylor and Francis, 2005

5. Datnow, Amanda, Hubbard, Lea, Mehan, Hugh, Extending Educational Reform: From One School to Many, Taylor and Francis, 2005;

6. Dimmock, C. A. J., Donoghue, T. A., Innovative School Principals and Restructuring: Life History Portraits of Successful Managers of Change, Taylor \& Francis, 2005;

7. $\quad$ Gherguţ, A., Management general și strategic în educaţie. Editura Polirom, Iași, 2007:

8. Iosifescu, S., et al., 2003. Management educațional. Editura CDRMO, Iași, p. 24, vol. 1, apud Everard, K. B. and Morris, G., (1996). Effective School Manangement. Ed. P. Chapman Publishing Ltd, London.;

9. Peter McCaffery, The HigherEducation Manager'sHandbook: Efeective Leadership and Management in UniversitiesandColleges, Routledge, 2018;

10. Tomlinson, Harry, Educational Management, Taylor and Francis, 2004;

11. Smyth, John, Critical Perspectives On Educational Leadership, Taylor \& Francis, 2005;

12. Voinea Cristina Maria, Audit intern între teorie și practică, ProUniversitaria, 2016;

13. Ministerul Finanțelor Publice, Metodologia de implementare a Standardului de control intern „Managementului riscurilor”, 2007

14. Ministerul Finanțelor Publice, UCAAPI, Îndrumar - Evaluarea riscurilor în pregătirea și realizarea misiunilor de audit public intern, 2014

15. Legea $\mathrm{nr}$. 672/2002 privind auditul public intern, republicată, auditul public intern

16. ORDONANŢ̆ DE URGENŢ̆ Nr. 109/2011 din 30 noiembrie 2011 privind guvernanţa corporativă a întreprinderilor publice

17. http://oaji.net/articles/2017/1425-1511180618.pdf

18. https://www.cafr.ro/uploads/PdA\%203\%202018-1d35.pdf 